\title{
ZAKAT INSTITUTION OF FINANCIAL TRANSPARENCY MODEL: AN EXPLANATORY RESEARCH
}

\author{
Muhamad Wahyudi $^{1}$, Nurul Huda ${ }^{2}$, Sri Herianingrum ${ }^{3}$, Ririn Tri Ratnasari ${ }^{4}$ \\ ${ }^{1,3,4}$ Fakultas Ekonomi dan Bisnis, Universitas Airlangga, Surabaya. ${ }^{2}$ Universitas YASRI
}

\begin{abstract}
Public demand for financial transparency of zakat institutions is getting stronger. The weak quality of financial reports resulted in a distrust of this institution. Therefore, a framework is needed as a reference in compiling and presenting quality financial reports that meetpublic expectations. This article aims to propose a financial transparency framework for the Amil Zakat Institution (LAZ) in Indonesia. This is a descriptive qualitative study with an explanatory approach. Furthermore, data collection was carried out through studies related to financial transparency of the institution and was complemented by interviews with directors, distribution managers, accounting staff, and three muzaki of zakat institutions in Central Java. The results concluded that the framework for transparency practice in the financial statements of zakat institutions comprises three parts, namely the principle of tauhid as a foundation component. Amil zakat professionalism, internal audit, internal control, and financial accounting standards are the principal components, aswell as the use of the website as support. The implication of this study is that the credibility of zakat institutions can be increased by improving the quality of financial reports.
\end{abstract}

Keywords: financial transparen; zakat institutions; explanatory research

Abstrak: Tuntutan masyarakat terhadap isu transparansi keuangan lembaga zakat semakin kuat. Kualitas laporan keuangan yang lemah menyebabkan ketidakpercayaan terhadap lembaga zakat. Diperlukan suatu framework sebagai acuan dalam menyusun dan menyajikan laporan keuangan yang berkualitas yang dapat memenuhi ekspektasi masyarakat. Artikel ini bertujuan mengusulkan kerangka kerja transparansi keuangan Lembaga Amil Zakat (LAZ) di Indonesia. Penelitian ini merupakan penelitian kualitatif deskriptif dengan pendekatan eksplanatori. Pengumpulan data dilakukan melalui studi literatur terkait isu transparansi keuangan lembaga zakat dan dilengkapi dengan wawancara dengan direktur, manajer distribusi, staf akuntansi dan tiga muzaki lembaga zakat di Jawa Tengah. Hasil penelitian menyimpulkan bahwa kerangka praktik transparansi laporan keuangan lembaga zakat terdiri dari tiga komponen yaitu: prinsip tauhid sebagai komponen pondasi. Profesionalisme amil zakat, audit internal, pengendalian internal dan standar akuntansi keuangan sebagai komponen utama dan penggunaan website sebagai komponen pendukung. Implikasi dari penelitian 
ini adalah dapat meningkatkan kredibilitas lembaga zakat dengan meningkatkan kualitas informasi laporan keuangan.

Kata kunci: transparansi keuangan; lembaga zakat; explanatory research

*Corresponding author: muhamad.wahyudi-2019@ feb.unair.ac.id

Received: January 04, 2021; Accepted: June 09, 2021; Published: September 30, 2021

\section{INTRODUCTION}

According to the Republic of Indonesia Government Regulation No. 24 of 2005 , financial transparency is the delivery of information to the public in an open and honest manner. This is a responsibility for the management of resources entrusted by the community to the government. In the non-profit organization,Ball, (2009)defined transparency as a good governance system that produces programs and policies. Meanwhile, the term transparency in zakat institutions is defined as the openness in managing funds, which is presented, as accountability to stakeholders (Puskas BAZNAS, 2019)

Islam places the principle of transparency as one of the principal methods of managing zakat institutions (Tahliani, 2018). The religion assesses that accountability and transparency are forms of the mandate given by God to humans (Islamic Accountability) (Saad et al., 2014). Also, empirical studies proved that the institution's openness can support the achievement of organizational goals and ensure sustainability in the future (Nasim \& Romdhon, 2014; Saad et al., 2017; Harris \& Neely, 2018; Nasri et al., 2019; Zadjuli, Shofawati, and Muryani, 2020). Transparency affects the level of legitimacy and public trust, especially muzaki in distributing zakat through the institutions (Nu Htay and Salman, 2013; Samargdani, 2018; Firmansyah dan Devi, 2017; N. Amalia, 2019; Aziz \& Anim, 2020).

Public trust, for non-profit organizations such as zakat is the most important element in supporting the survival of the institution. In a sociological view, trust is interpreted as a condition of a party's dependence on the behavior of another in carrying out certain activities (Ghazali, 2016). This definition is relevant when used to describe public trust in these institutions. This can be seen from the dependence on muzaki in using them to distribute zakat, infaq, and alms to be the principal support for the running of the organization. Public trust is determined by the extent to which zakat institutions are committed to practicing good governance, and to what degree the quality of public accountability is conveyed (Murtala et al. 2011; Kashif et al., 2018;R.A.J. Saad et al., 2020).

Currently, non-profit organizations around the world face increasingly strong demands for the quality of financial accountability and transparency (Verbruggen et al., 2011). The zakat institutions as non-profit organizations that manage public funds also faced the same demands. (Puskas BAZNAS, 2019). Even though the government has issued Law no. 23 of 2011 and Government Regulation No. 14 of 2014 articles $71-76$ concerning the obligations of these institutions to submit financial reports, their financial transparency is still considered low 
(Puspitasari and Habiburrochman, 2013; Nikmatuniayah, 2015; Hasibuan, 2016; Karim et al.2019; Hermawan and Rini, 2016; Taha et al., 2017; Rizkaa Nurfadhilah and Sasongko, 2019).

Amalia et al., (2018)stated that the weak practice of financial transparency of these institutions was due to several reasons, namely differences in using transparency indicators, variation in interpreting the concept, and the patterns of financial report publication. Meanwhile, Sapingi and Nelson, (2016), stated that due to the non-compliance of zakat institutions with transparency provisions, there is an absence of a supervisory body and accounting standards as reporting and disclosure guidelines.

Basedon these facts, it is necessary to conduct a study that provides comprehensive guidance for these institutions on how to present financial transparency, elements that support openness, and how to publish the reports to the public. The limited comprehensive literature concerning this issue shows the importance of this study. Therefore, this study aims to propose a model of financial transparency of zakat institutions to increase their accountability. The implication is to assist these institutions toincrease credibility of the organization through the disclosure of quality and transparent financial reports

\section{RESEARCH METHODS}

This is a qualitative study with an explanatory approach (FrankfortNachmias et al., 1992). The data were from literature reviews (Mestika, 2008) and interviews. Librarian studies were carried out on articles related to the financial transparency of zakat institutions in national and international journals. Furthermore, interviews were conducted with the director, distribution manager, accounting staff, and two muzaki (regular donors) at the Dua'fa Humanitarian Fund zakat institution (DKD), Magelang City, Central Java. Also, a descriptive analysis was used, and the study wasconducted in different stages. In the first stage conducted a literature review related to the topic. In carrying out this survey, the research team grouped theliterature into 6 focus issues, namely (a) Islamic accountability theory, (b) the quality of financial information characteristics, (c) the role of amil zakat professionalism, (d) role of internal audit, (e) the role of internal control, and (e) web-based accountability issues. The second stage involved conducting semi-structured interviews with five informants comprising 3 amil zakat people and two muzaki. Meanwhile, the third stage is based on the results of the literature review and assessments that have been conducted. Subsequently, the research team built a theoretical framework for financial transparency studies on zakat institutions. In stage four, a model for transparency was developed based on the framework. The fifth stage involved discussion and justification of the financial transparency model.

\section{RESULTS AND DISCUSSION}

\section{Design a Model For Financial Transparency of Zakat Institutions}

Based on the literature review, the research team concluded that five variables affected the quality of accounting reports. These variables include the use of financial accounting standards, internal audit, internal control, professionalism of 
amil zakat, and information technology systems. Based on the results, a theoretical framework for the practice of financial reporting transparency in zakat institutions can be formulated, as shown in Figure 1 below:

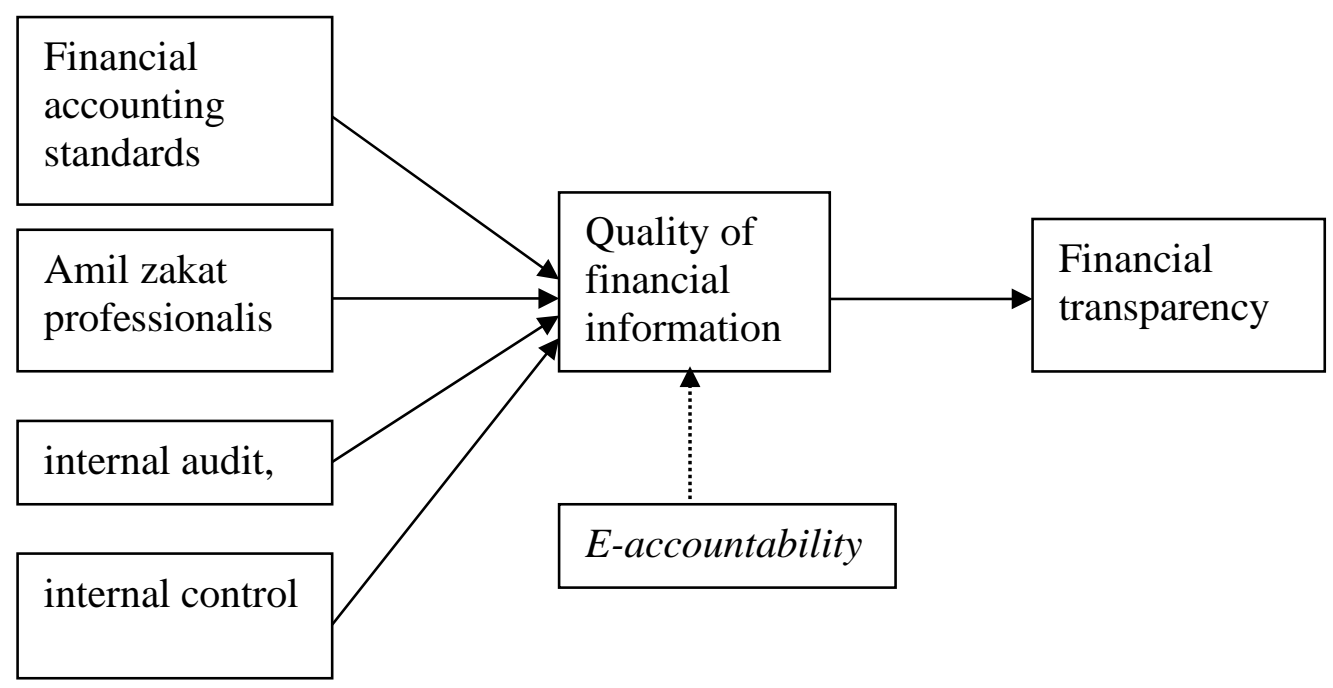

Figure 1. The Theoretical Framework for the Practice of Financial Transparency of Zakat Institutions

Source: developed from previous research

Furthermore, based on the five variables in the theoretical framework above, a model of financial transparency wasdeveloped by adding one more variable, whichis the principle of Tauhid. Thesewere grouped into three categories, namely the foundation component with Tauhid as its principle, the principal component that comprises four variables, including financial accounting standards, amil zakat professionalism, internal audit, and internal control variables. Last, the supporting component, whichincludes the e-accountability variable.

The model for the financial transparency framework of these institutions as proposed is presented in Figure 2. below. 


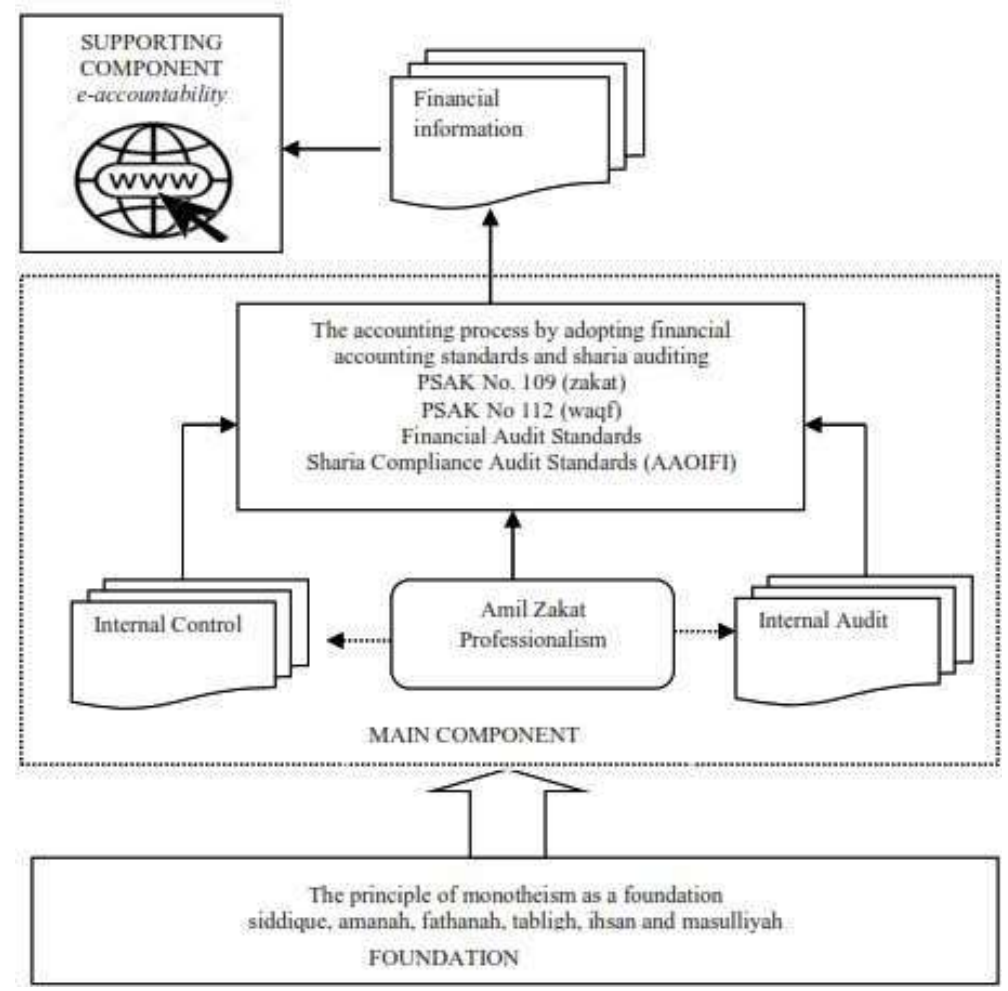

Figure 1. zakat institution financial transparency model

Source: a theoretical study

\section{Review of the Model of Financial Transparency of Zakat Institutions and Justification}

\section{The Principle of Tauhid as the Foundation for Financial Transparency of Zakat Institutions}

The crisis in the credibility of Islamic charities in the world has led to the emergence of various alternative solutions. One of which is by conceptualizing Islamic values in developing good accountability practices. Islam is believed to be a holy religion that teaches noble principles as the foundation for running good organizational governance. Ghafran and Yasmin, (2019) designed an ethical framework in organizational management. Three values were proposed in the management of Islamic organizations, namely (1) work is a means of upholding justice and truth. Therefore, the organizational mechanism should be directed to get the blessings and goodness of the world and the (falah); (2) Principles of decision making based on the values of justice, trust,ihsan, and faith; and (3) The value of individual professionalism, which is supported by the characteristics of siddique, amanah, fathanah, tabligh, ihsan and masulliyah.

Islamic teachings strongly emphasize a Muslim to be sincere and responsible in carrying out every mandate. This is the word of Allah in the Qur'an surah Al-Anfaal verse 27, which stated "O ye that believe! Betray not the trust of 
Allah and the Messenger, nor misappropriate knowingly things entrusted to you". (Al-Anfaal 8:27). The obligation to carry out the commandment is one of the requirements for the perfect faith of a Muslim. As were the words of the Prophet Muhammad SAW, which means:"There is no perfect faith for people who do not have trustworthiness, and there is no religion for those who do not keep promises" (HR.Ahmad). Based on the fragments of the letter Al-Anfaal and the hadith of the prophet above, it can be understood that carrying out the mandate is an obligation and is part of the perfection of a Muslim's faith.

Managing zakat institutions is also an injunction given by Allah to humans. The duty is essentially a means to carry out the mandate of humans as caliphs. Triyuwono, (2001), modeled how to carry this out in the metaphorical concept of Amanah. The Amanah metaphor defines organizational management as an instrument or means to carry out the noble duties of caliphs on earth (Kalbarini and Suprayogi, 2015). Choudhury and Hogue, (2004) in Hasan, (2009) stated that Tauhid is the basic foundation of Islamic teachings which serves as a basis in every human activity. In organizational management, the principle of Tauhid becomes the basic framework for implementing organizational governance (Z. Hasan, 2009). Also, Malik, (2016) stated that the principle of Tawhid in Islamic Governance practices is the fundamental basis for upholding truth and justice with an ukhuwah frame to achieve happiness in the world and the hereafter (falah).

This principle is the basis of all the activities of a Muslim. As regards economic activity, all Islamic economists have agreed that monotheism is a stepping stone in taking action and deciding ( $\mathrm{Z}$. Hasan, 2002). The main components of these principles are the values of justice, honesty which is based on siddique (honest), trustworthy (trustworthy), fathanah (intelligent/knowledgeable), tabligh (conveying the truth), ihsan (doing good), and masulliyah (leadership) (Tapanjeh, 2009).Tapanjeh, (2009) is of the opinion that in economic activities, this principle has resulted in the concept of Islamic Governance (Islamic governance). The tenets of Islamic Governance include the principles of accountability, disclosure, transparency, bookkeeping (accounting activities), and last accounts (final reports). Accountability and disclosure in Islamic view should be carried out in a fair and transparent manner. The exercise of accountability is directed first of all to God. Furthermore, the responsibility to God is a form of a conviction that everything in man is an injunction from Allah and should be accountable. The next accountabilityis addressed to all relevant stakeholders.

In the context of accountability for zakat institutions, the principle of transparency is fundamental to the Islamic accounting system. In implementing this principle, these institutions should present quality financial information that meets aspects of justice and honesty, to be useful in making correct decisions. Therefore, financial statements should be disclosed in a precise and transparent manner.

Regarding bookkeeping activities (accounting activities) and final reports, Islam strongly emphasizes that every financial transaction should be recorded fairly because it will be accounted for before Allah. The Qur'an clearly emphasized this matter, as stated in the Qur'an, Surah Al-Baqarah: 282, which means: "O people who believe, when you make a debt (transact) for a specified time, let you write it down. (record and book it) ". QS. Al-Baqarah: 282. Allah has also commanded each 
servant who is given the mandate to be fair, as conveyed in Surat Al-Anbiya: 47, which means:

\begin{abstract}
"We will set the correct scales on the Day of judgment, and no one will lose anything. And if (the practice) it is only as heavy as a mustard seed, we will definitely bring it (reward). And it is sufficient for us as calculation makers." QS. Al-Anbiya: 47.
\end{abstract}

From the contents of the above verse, it can be understood that Islam has mandated it for every Muslim to write every financial transaction honestly and fairly, carry out every mandate received seriously and responsibly. In Islamic teachings, accountability and transparency are basic ethical values for every Muslim. It is therefore clear that financial reporting and accounting practices should be carried out based on the spirit of Islamic teachings.

Furthermore, Ahmad Rafi, director of the Du'afa Humanitarian Fund zakat institution, explained that spiritual development for all employees, which is carried out regularly is a very important tool in creating awareness to make religious values the basis for carrying out their duties. This coaching program is considered having changed the mindset of employees from the intention of just working to the mindset of worship and hoping for the pleasure of Allah.

Motivation and work ethic based on the spirit of hoping for pleasing Allah has given rise to public trust in the organization. This can be seen from the statement of Suharyanto, a donor who always entrusted the payment of zakat through the Dompet Duafa Humanitarian Fund who, after explanations, believed that the zakat paid would be managed in a trustworthy manner. It is believed that giving zakat through these institutions, will be more useful. Suharyanto's explanation was supported by Suryani, another muzaki who is very pleased with the programs being rolled out, for example, the Qur'an house. The reputation of the employees who were polite, and trustworthy made them believe that the funds they submit will be properly accounted for.

These institutions that use Islamic values as an operational basis should put the principle of Tauhid as the basis or foundation for all the elements. The existence of these institutions which have a role in facilitating a Muslim to fulfill religious orders as paying zakat should be the principle of Tauhid as a moral foundation. Thiswill create a commitment to carry out the mandate effectively. The spiritual development program for all employees is very significant in shaping the moral strength of all amil zakats, which can generate trust from muzaki.

\title{
The professionalism of Amil Zakat as the Main Component of Financial Transparency of Zakat Institutions.
}

As understood, the existence of an organization cannot be separated from the availability of quality human resources. Every organization needs human resources for sustainability, which will affect its success in achieving setgoals. Likewise, the availability of professional human resources in the financial sector will determine the quality of financial information produced (Nasri et al., 2019). Firmansyah and Devi, (2017) revealed that to improve the quality of good 
governance, the dominant strategy that zakat institutions should implement is the availability of a good human resource management system. In this context, professionals are the key to success in improving organizational performance.

A study conducted by Harris and Neely (2018) on over 14,000 non-profit organizations in the world found consistent evidence that organizations with a good level of transparency are influenced by professional staff. This study is also supported by the results of Verbruggen et al., (2011) on non-profit organizations in Belgium, which concluded that the dependence of non-profit organizations on human resources determines the quality of financial information.

Concerning zakat institutions, the human resources referred to in this context are amil zakat. Competent amil zakat will produce an excellent performance for the institutions. In fact, their competence in finance is needed to produce quality financial information. However, limited competence in compiling correct reports will have a negative effect on the quality of the financial information produced, which affects the level of confidence. According to Naz'aina, (2015) the competence of amil zakat is reflected in three things, namely basic knowledge, skills, and experience. Basic knowledge is related to how correct financial statements are prepared. Therefore, skills, experience, and knowledge in mastering accounting techniques determine the quality of financial information.

The professionalism of amil zakat is one of the major components that significantly affects the quality of financial information on these institutions (Astuti and Themba, 2020; Qurratu'ain et al., 2020 andNaz'aina, 2015). According to Adnan et al., (2013), professionalism refers to intellectual capital which includes competence, knowledge, experience, and skills. Meanwhile, human resources are valuable intellectual capital for these institutions. Hameed et al., (2004) stated that the professional criteria for an amil zakat include having faith in Allah, being cautious, ihsan, integrity, objectivity, competence, being able to maintain confidentiality, and professional behavior. In relation to the quality of transparency, an amil should have financial competence, especially in accounting. The competence of those who are qualified in financial accounting is seen from their ability to produce reports under applicable accounting standards (Nasri et al., 2019). Besides mastering accounting standards, professional amil zakat is also required to master and understand the various regulations and policies related to finance and have skills in using information technology.

Regarding the professionalism of amil zakat, Ahmad Rafi explained that the fundamental problem is frequent employee turnover. Becoming an amil zakat is not a dream profession. Employees often go in and out because they got a better job. In this situation, the management could not do much. In addition, it was emphasized that all staff have a bachelor's degree and have relevant educational backgrounds, some even graduated from high school. However, management is always trying to improve employee competence by facilitating them with training activities.

The existence of quality human resources for some of these institutions is still a serious problem, especiallyregarding career path and welfare issues. The future of careers and the level of welfare are the fundamental problems in obtaining qualified human resources. Therefore, zakat institutions need to develop a good human resource management system to produce professionals. A. Hasan et al., 
(2019), regarding professionalism stated that the existence of HRM (Human Resource Management) to pay attention to the key elements including the recruitment process, performance appraisal, training, and development, as well as clarity of compensation or welfare issues is emphasized

Regarding careers and compensation for amil zakat, the emergence of a discourse on professional certification programs in various opportunities is encouraged. BAZNAS has launched a certification program as a priority in 2021 . This certification is indeed important to improve the status of amil zakat, hence, it is no longer just a "side" gig but actually a choice of a profession that is recognized and equal to others. Furthermore, policies related to their welfare standards should be considered. Currently, there are no provisions regarding their compensation standards. This issue is still left to the policies of each zakat institution. Therefore, it is necessary that the amil zakat professional certification program be carried out with the formulation of policies related to the standardization of compensation. This is important for their professionalism in meeting the current demands.

\section{Internal Audit and Quality of Financial Information}

An internal audit is an assessment carried out independently within an organization to test and evaluate operations. Furthermore, it is conducted to provide information to stakeholders about the condition of the organization (Hakim et al., 2019). Internal audit helps toachieve objectives through a systematic approach to evaluate and improve the effectiveness of risk management, control, and governance processes (Shamsuddin et al., 2017).

Conventional literature stated that accounting information results from a long procedure called the accounting process. The quality of accounting information is determined by compliance with the guidelines used. The existence of internal audit as an element that guards the accounting process starting from the activities of recognition, measurement, presentation to the disclosure will determine the quality of the financial information produced. Also, internal auditors maintain the running of an organization from irregularities. In addition, it plays a role in overseeing compliance with various regulations, efficiency policies, and preventing various possible fraudulent acts (Erfiansyah and Kurnia, 2018).

For these institutions, internal audit has a very strategic role. The role of this audit is to control various areas such as management, operations, information technology, finance, fraud, and organizational business activities (Wulan et al., 2018). In addition, the role of internal audit isto confirm, verify compliance with financial policies, laws and regulations, administrative systems, and public policy adoption (Shamsuddin et al., 2018). It plays an important role in ensuring the reliability of financial statements (Cooper, 2012).

In a study conducted by Shamsuddin et al., (2017), the internal audit structure in zakat institutions should be formed in its independent department. It should also be led by people with experience in auditing and staff members with various scientific backgrounds, especially experience in accounting and mastering information technology. The results of empirical studies have confirmed that the existence of internal audits at zakat institutions has improved the quality of financial information (Zainon et al., 2014; Erfiansyah and Kurnia, 2018). 
The provisions regarding an internal audit for zakat institutions in Indonesia are contained in the 15th core principle of Zakat Core Principle (ZCP) concerning sharia control and internal audit. In the 15th principle, it is stated that these institutions are expected to form an internal audit committee in the organization. The formation of this committee aims to achieve the principles of organizational accountability and transparency, as well as compliance with sharia regulations. In this principle, the institutions are required to have appropriate financial and sharia controls within an effective internal audit framework. This is one of the core beliefs of zakat institution governance, especially in Indonesia. The internal audit framework isalso intended to establish and maintain its operations to run effectively. Here, to ensure the accountability of financial report transparency, an internal audit of the financial statements was carried out by an inner agency or department of a zakat institution known as the internal audit committee. Meanwhile, to ensure that the operations did not deviate from sharia provisions, sharia compliance audits were conducted.

Internal audits at several zakat institutions for certain reasons have not been carried out. However, the supervision and examination of the financial statements are still carried out by the direct supervisor. This is as explained by Eva, whois a staff of the accounting department. It was explained that the absence of a special audit department did not prevent the financial statements from being audited. The manager as the direct supervisor always checks the statements made. It was explained that the statements were always audited yearly by a public accountant.

The absence of an audit department in most of these institutions is suspected to be due to the efficiency of the expenditure budget. However, the need for an ideal organizational structure remains the hope of every zakat institution. This is as explained by Ahmad Rafi, that although the institution for efficiency reasons does not yet have an audit department, there is hope that it would when the budget allows for an ideal organizational structure to be formed.

This is in line with Assalafiyah and Rusydiana, (2020), which stated that concerning an internal audit, zakat institutions still face three main problems, namely (1) the number of sharia auditors is insufficient, (2) there is no strong rule related to sharia auditing and (3) lack of competence in human resources. However, it is believed that this does not reduce the commitment to form an internal audit committee and provide full support to function effectively.

\section{Internal Control and Financial Transparency of Zakat Institutions}

Internal control is one of the management functions to achieve institutional goals. Every manager of an organization must ensure that implementing internal control is effective. The definition of internal control according to the Committee of Sponsoring Organizations of The Treadway Commission (COSO, 2009), is an effective process of organizational structure, management, and all personnel designed to ensure goals achievement. This is related to the reliability of financial statements, operational effectiveness, efficiency, and organizational compliance. Regarding COSO (2009), there are five components of internal control, namely (1) environmental, (2) risk, (3) activity, (4) information and communication control, 
and (5) activity monitoring (Kamarudin and Ramli, 2015). The effectiveness of internal control can ensure the running of the organization effectively and efficiently (Naz'aina, 2015).Previous studies have shown that the effectiveness of internal control has a significant effect on the quality of financial information (Naz'aina, 2015; Kamarudin and Ramli, 2015; Apriliani and Jayanto, 2017; Mediawati, 2016).

For non-profit organizations, the activity control component is the most important part. This control is related to the activities of collecting and distributing zakat funds. The effectiveness of activity control will increase the accountability of the institutions. According to Sulaiman et al., (2017), in the latest edition of Internal Control - Integrated Framework, there are five main activities in controlling activities, namely (1) there is a clear separation of duties, (2) distribution of policies for authorization, and approval of budget use, (3) verification and reconciliation policies, (4) adequate physical control policies, and (5) the effectiveness of independent examinations (COSO, 2009).

This control is one of the major elements that should be present in the organizational governance system. Its existence is very beneficial for these institutions because it can prevent various risks that may occur. Some risks of zakat institutions as contained in the Zakat Core Principle (ZCP), include the risk of transfers between countries (11th principle), reputation and reduced trust (12th principle), allocation (13th principle),aswell as operational and sharia risks (14th principle ). Therefore, the internal control function should be the focus of management to ensure they are avoided.

Reputation hazards and reduced trust (principle 12) are related to issues of financial accountability and transparency. The decline in reputation and reduced stakeholder trust can occur because the accountability of the financial statements submitted is not of high quality. Internal control is needed to produce quality financial reports. There are five internal control activities related to transparency of financial accountability, namely segregation of duties, transaction authorization, documentation and recording, physical control of assets, and independent inspection (Kamarudin and Ramli, 2015).

In relation to the primary function of the zakat institution that carries out the intermediation function, there has been a clear separation between the collection and distribution functions of zakat. Setiaji, the coordinator of the distribution program, explained that the separation of duties and responsibilities between collection and distribution has been effectively carried out. Each field worked according to its respective tupoksi, regarding the accounting function. The separation of duties between the revenue and expenditure functions has also been carried out. This is confirmed by the statement of Eva, who explained that there had been a division of responsibilities between the activities of recording receipts and expenditures. Therefore, accounting records are periodically synchronized with other departments to get report accuracy.

Documentation and record-keeping activities are key actions of internal control. In this activity, the use of information technology by the institutions is highly recommended. Using information technology in documentation and recording or accounting duties can minimize the risk of errors. Using accounting 
software such as Quick Book or SIMBA (financial information technology from BAZNAS) to compile financial reports will produce higher-quality financial information.

Physical asset control is the activity of securing or protecting organizational assets from theft or damage due to disaster. Using a safe, provision of a special room to store documents and assets, use of CCTV, and an early fire detection system is part of the asset control system. As much as possible, zakat institutions should strive for an excellent security system to protect assets.

Ahmad Rafi explained that concerning internal control, all activities ranging from collection, distribution, to finance are supported by adequate standard operating procedures. It was stated that evaluation activities were always carried out to improve SOPs.

The essence of internal control is the availability of standard operating procedures (SOPs) at zakat institutions. Therefore, they should meet the adequacy of SOPs to ensure that they operate effectively. Meanwhile, regarding inspection or audit activities by independent parties, it is an element of internal control that should not be overlooked. The financial report audit is carried out by a public accountant. This audit is carried out to assure that the financial statements that have been prepared are free from irregularities of information either caused by acts of fraud (fraud) or human error (human error). In addition, it ensures that the financial statements are prepared under applicable financial standards.

As regards independent audits, it is contained in the 16th Zakat Core Principle (ZCP) regarding financial reporting and external auditing. In this principle, implementing external audits is part of internal control, which is the core principle of good zakat governance. In addition, the obligation of these institutions to submit financial reports that have been audited by an independent auditor to BAZNAS has also been stated in Law Number 23 of 2011.

\section{Financial Accounting Standards and Financial Transparency of Zakat Institutions}

A literature review related to the quality of accounting information is an important need for accounting standards (Firmansyah and Devi, 2017). The research team stated that the quality of financial reports as transparency should meet standard criteria and be generated from an accounting system. Nu Htay and Salman, (2013) in their study of best practices for financial information disclosure of zakat institutions in Malaysia, recommended 7 things that should be disclosed in financial reports, namely (1) Financial reports should refer to applicable accounting standards or guidelines (for example, MASB, IFRS, GAAP), (2) disclose of the accounting policies used to receive zakat, for example, cash or accrual basis, (3) explanation of changes in accounting principles used, (4) disclosure of error corrections in the previous year, (5) supervisory board information, (6) information on the remuneration policy of the supervisory board and management, and (7) information on the remuneration of each supervisory board.

Pamuncak et al., (2018) argued through their study that to meet the need for the quality of accounting information for stakeholders, the institutions can adopt International Financial Reporting Standards (IFRS). IFRS is an internationally 
accepted accounting standard. Also, it was found that in IFRS, there are 11 articles of standard statements that can be adopted in preparing financial reports.

Meanwhile, in Indonesia, the accounting standards have been regulated in Statement of Financial Accounting Standards (PSAK) Number 109 concerning zakat and accounting for donations/alms and number 112 regarding waqf. PSAK No. 109 and 112 are used as guidelines for preparing financial reports starting from the recognition, measurement, presentation, and disclosure of zakat and infaq / alms and waqf transactions (Irti and Susanto, 2019). The financial statements according to PSAK No. 109 composed of (1) Balance Sheet (Statement of Financial Position). Neracara is a report that presence the position of assets and obligations of the zakat institution. (2) Change Report,which contains information on changes in zakat funds, infaq / alms funds, amil, and non-halal funds. (3) Asset Change Report contains information on changes in assets under management. (4) Cash Flow Statement. (5) Notes to Financial Statements. This explains the various accounts presented in the financial statements. Besides those mentioned above, zakat institutions should also disclose other things, suchas the accounting policies used to acknowledge receipts, the reasons for changes, the remuneration policy of the supervisory board and management, and correction of errors in the previous period. Furthermore, the financial statements of these institutions should also meet the principle of full disclosure in presenting the information. Also, information regarding the collection and distribution of zakat, infaq, and sodaqah should be disclosed. Several things need to be disclosed, namely details of the amount of zakat received and distribution from each category, analysis of efficiency ratios, collection and division charts, distribution and collection and, costs, aswell as the percentage in each category, compared to the total distribution amount (Nelson et al., 2017).

Based on the applicable Financial Accounting Standards, the quality of statements is determined by the contained characteristics. There are four characteristics of the quality of financial information that should be considered in preparing reports, namely understandable, relevant, reliable, and comparable (Apriliani and Jayanto, 2017).

Based on the description above, it can be concluded that these institutions should adopt financial accounting standards in preparing reports. The standard in Indonesia is PSAK No. 109 concerning zakat and 112 regarding waqf. In addition, to conduct audits, both financial and sharia compliance audits, zakat institutions should adopt applicable audit standards, such as those issued by AAOIFI (Accounting and Auditing Organization for Islamic Financial Institutions). Adherence to accounting and auditing standards will produce quality and useful financial reports for users, especially muzaki, to decide on paying zakat.

Related to this accounting standard implementation, there are still problems, one of which is the lack of understanding of the department employees, due to irrelevant educational backgrounds or lack of training from BAZNAS. Thiswas explained by Eva that there was difficulty understanding the contents of PSAK due to a lack of educational accounting background. Therefore, help from BAZNAS is necessary to provide guidance or training in preparing financial reports. 
The problems above are common issues faced by many of these institutions. Hence, the right solution is needed, especially from BAZNAS, as the party responsible for financing and assisting zakat institutions in Indonesia. It is necessary to intensify training and mentoring programs to prepare financial reports to comply with applicable accounting standards. Several studies have also revealed that the absence of a standard for implementing financial audits and sharia compliance audits is an issue that needs an immediate solution.

\section{Web-based Accountability and Financial Transparency of Zakat Institutions}

According to Sarman et al., (2015), Web-based accountability is defined as the practice of organizational accountability through the delivery of reports and feedback mechanisms online using the website. Lee and Bhattacherjee, (2015) found that the development of Internet-based information technology, especially websites, has changed the governance of non-profit organizations to be more innovative and creative in response to challenges. Likewise, according to Saxton dan Guo (2011); Connolly and Dhanani (2013), the use of websites by non-profit organizations is more emphasized to convey organizational accountability to the public. Therefore, the website is prioritized for delivering performance and financial reports rather than as a medium for interactive communication with stakeholders.

Saxton and Guo, (2011) and Gdanía, (2011) found out that online accountability disclosure using the website plays an important role in gaining sympathy from donors. This is evidenced because various social fundraising program websites have appeared that easily get responses from volunteers and donors. This proved that the effectiveness of an organization's website plays an important role in gaining legitimacy from stakeholders. The internet and websites have become significant media for accountability to gain public legitimacy (Connolly and Dhanani, 2013; Samkin and Schneider, 2010).

Connolly and Dhanani (2013) found that internet technology is a very effective medium considering its various advantages such as wide and efficient access, the ability to communicate in real-time with stakeholders and to integrate with other digital technologies. Therefore, it can be the primary choice of non-profit organizations in increasing transparency of financial accountability and public involvement (Samkin and Schneider, 2010).

The development of communication technology, especially the internet, has resulted in significant changes in various business and social activities. Using the internet (website) to convey public accountability has become the right choice and has even become a public demand. This is because the internet has become a lifestyle for most people today. Its presence makes information easily accessible. According to Saxton and Guo, (2011)and Gdanía, (2011), the use of websites in delivering the accountability of philanthropic institutions affects the positive perceptions of donors.

Website-based accountability is very effective in building organizational credibility. However, empirical evidence found that the use of websites for 
transparency in the accountability of these institutions in Indonesia is still low (Karim et al., 2019; Rini, 2016; Sapingi \& Nelson, 2016), including non-profit organizations (Lee \& Joseph, 2013). Some reasons for this are the unpreparedness to face technological developments, the resistance to information technology (Lee \& Joseph, 2013), absence of strict regulations regarding the obligation to publish financial reports using the website (Karim et al., 2019). Other reasons include the inconsistency of zakat institutions and the existence of various internal factors that are difficult for the public to understand (Sapingi \& Nelson, 2016).

For some institutions, the website is still only a static information medium. Its use is still limited to promotional purposes and has not been directed as an accountability tool. This is based on the experience conveyed by Ahmad Rafi. In addition, the lack of human resources who have the ability in information technology in managing the website is one of the reasons why it is not optimal.

Although there are various challenges faced by these institutions in utilizing the website as a means of public accountability, this should not discourage them from trying to find the best alternative given the strategic role it plays in building credibility. Also, field experience proved that one of the factors that determine the intention of muzaki to use these institutions to pay zakat is the existence of a website.

Empirical facts also proved that one of the factors that determine muzakki's intention to choose an institution to pay zakat is the existence of a website. This is as stated by Suharyanto, a donor who explained that the decision to distribute zakat through them was due to an interest in social programs that were read through the zakat institution's website.

Using websites as a medium for delivering financial reports will increase the transparency of these institutions. The internet and websites are significant media for accountability to gain public legitimacy (Connolly \& Dhanani, 2013; Samkin \& Schneider, 2010). Moreover, the maximum use of the website will increase public participation in various social programs launched by zakat institutions. Therefore, they should be able to follow the trend of people's lifestyles related to this information technology.

Based on the description above, the financial transparency model of zakat institutions can be summarized more concisely in the explanation in table 1. below:

Table.1 Description of the Zakat Institution's Financial Transparency Model Components

\begin{tabular}{ll}
\hline Component & \multicolumn{1}{c}{ Description } \\
\hline Foundation & $\begin{array}{l}\text { The value of faith (Tauhid) is a foundation in carrying out the mandate by } \\
\text { components } \\
\text { upholding the values of justice, honesty based on siddique (honest), } \\
\text { trustworthiness (trustworthy), fathanah (intelligent/knowledgeable), } \\
\text { tabligh (conveying the truth), and masulliyah (leadership). }\end{array}$ \\
\hline $\begin{array}{l}\text { Principal } \\
\text { component }\end{array}$ & $\begin{array}{l}\text { 1. Amil zakat professionalism is manifested through faith in Allah, } \\
\text { piousness, ihsan, integrity, objective competence, firmness in } \\
\text { maintaining confidentiality, and professional behavior (professional } \\
\text { of conduct) }\end{array}$ \\
\hline
\end{tabular}


2. Internal audit is an activity to confirm, verify the compliance of zakat institutions with financial policies, administration, laws and regulations, administrative systems, and public policy adoption.

3. Internal control is a set of systems to ensure the operation of zakat institutions in achieving predetermined goals.

4. Accounting standards are statements of financial accounting standards in PSAK 109

Supporting Web-based accountability, a mechanism for delivering financial component accountability using website media.

\section{CONCLUSION}

Financial transparency has become a widespread demand for Islamic philanthropic institutions, especially zakat. The practice of transparency and accountability of these institutions is still considered weak. Hence, a more comprehensive strategy and approach are needed to increase transparency and accountability. Also, the framework for the practice of transparency in financial statements is a more comprehensive approach. Six variables determine the quality of the financial reports of zakat institutions, namely the professionalism of amil zakat, the tauhid variable, financial accounting standards, internal audit, internal control, and information technology. The implication of this study will increase the credibility of zakat institutions, which can optimize their performance in collecting funds. However, the limitation is that this was a conceptual study and only focused on aspects of financial transparency. Therefore, it is necessary to conduct an empirical study to get a solid scientific foundation as a basis for deciding.

\section{REFERENCES}

Adnan, N. S., Kamaluddi, A., \& Kasim, N. (2013). Intellectual capital in religious organisations: Malaysian zakat institutions perspective. Middle East Journal of Scientific Research, 16(3), 368-377.

Amalia, E., Rodoni, A., \& Tahliani, H. (2018). Good Governance in Strengthening the Performance of Zakat Institutions in Indonesia. 2018, 223-241.

Apriliani, E., \& Jayanto, P. Y. (2017). Analysis of Determinant of Financial Statements Quality of Amil Zakat Agencies in Semarang City. Accounting Analysis Journal, 6(2), 264-276.

Astuti, N. P., \& Themba, O. S. (2020). Sharia Compliance, Human Resource Competencies, Quality of Accounting and Accountability Information on Management of .... Jurnal Kemanusiaan, 1(23), 99-104.

Ball, C. (2009). What Is Transparency? Public Integrity, 11(4), 293-308.

Connolly, C., \& Dhanani, A. (2013). Exploring the discharge of e-countability by charities. Journal of Applied Accounting Research, 14(2), 108-126.

Cooper, B. J. (2012). The Audit Committee and Internal Audit. Managerial Auditing Journal, 8(3), 8-10. 
COSO. (2009). COSO Internal control-integrated framework: Guidance on monitoring internal control systems, Volume III: Examples: Vol. III (Volume III). American Institute of Certified Public Accountants (AUCPA).

Erfiansyah, E., \& Kurnia, I. (2018). Peranan Auditor Internal Terhadap Kualitas Pelaporan Keuangan. Jurnal Ilmiah Manajemen, Ekonomi, \& Akuntansi (MEA), 2(2), 144-160.

Firmansyah, I., \& Devi, A. (2017). The Implementation Strategies of Good Corporate Governance for Zakat Institutions in Indonesia. International Journal of Zakat, 2(2), 85-97.

Frankfort-Nachmias, C., Nachmias, D., \& Nachmias, D. (1992). Research methods in the social sciences. St. Martin's Press.

Gandía, J. L. (2011). Internet disclosure by nonprofit organizations: Empirical evidence of nongovernmental organizations for development in Spain. Nonprofit and Voluntary Sector Quarterly, 40(1), 57-78.

Ghafran, C., \& Yasmin, S. (2019). Ethical Governance: Insight from the Islamic Perspective and an Empirical Enquiry. Journal of Business Ethics, 9(5), 1-21. Ghazali, M. Z. (2016). Proposing Factors Influencing Trust towards Zakat Institutions amongst Moslem Business Owners. ISSC 2016: International Soft Science Conference, 651-658.

Hakim, C. M., Ascarya, Beik, I. S., Pramono, S. E., \& Saoqi, A. A. Y. (2019). Designing Internal Audit Standard for Zakat Management Organization: Indonesia Experience. Pusat Kajian Strategis BAZNAS, 1-15.

Hameed, S., Wirman, A., Alrazi, B., Nazli, M., \& Pramono, S. (2004). Alternative Disclosure and Performance Measures for Islamic Banks. Second Conference on Administrative Sciences: Meeting the Challenges of the Globalization Age, King Fahd University of Petroleum \& Minerals, Dhahran, Saudi Arabia, 1921.

Harris, E. E., \& Neely, D. (2018). Determinants and Consequences of Nonprofit Transparency. Journal of Accounting, Auditing and Finance.

Hasan, A., Hassan, R., Engku Ali, E. R. A., Engku Ali, E. M. T., Abduh, M., \& Noordin, N. H. (2019). A proposed human resource management model for zakat institutions in Malaysia. ISRA International Journal of Islamic Finance, 11(1), 98-109.

Hasan, Z. (2002). Conceptual Definition of Corporate Governance Defining Corporation. Islam Zeitschrift Für Geschichte Und Kultur Des Islamischen Orients, 1-19.

Hasan, Z. (2009). Corporate Governance from Western and Islamic Perspectives. The Islamic Quarterly, 53(1), 39-65.

Hasibuan, H. . T. (2016). Statement of Financial Accounting Standard (PSAK) No. 109 and Its Implementation in Several Zakat Management Organizations in Malang, East Java. Shirkah: Journal of Economics and Business, 1(3), 339354.

Hermawan, S., \& R. W. Rini. (2016). Pengelolaan Dana Zakat, Infaq, dan Shadaqah Perspektif Shariah Enterprise Theory. Riset Akuntansi Dan Keuangan Indonesia, 1(1).

Irti, I. K., \& Susanto, H. (2019). Utilization Of Zakat , Infaq, And Alms ( Zis ) That 
Is Productive Of Transparency And Accountability In Indonesia. Proceeding Internastional Seminar on Islamic Studies, 1(109), 816-821.

Kalbarini, R. Y., \& Suprayogi, N. (2015). Implementasi Akuntabilitas Dalam Konsep Metafora Amanah di Lembaga Bisnis Syariah (Studi Kasus: Swalayan Pamella Yogyakarta). Jurnal Ekonomi Syariah Teori Dan Terapan, 1(7), 506.

Kamarudin, M. I. H., \& Ramli, N. M. (2015). Internal Control Practices in Islamic Non-Profit Organization in Malaysia. Proceedings of The Islamic Economic System Conference 2015 (IECONS 2015), March 2016, 511-527.

Karim, N. K., Sasanti, E. E., Lenap, I. P., \& Sari, N. K. (2019). Transparansi dan Akuntabilitas Pengelolaan Dana Zakat Berbasis Website Pada Lembaga Pengelola Zakat di Indonesia. Jurnal Riset Akuntansi Aksioma, 18(2), 13-28.

Kashif, M., Jamal, K. F., \& Rehman, M. A. (2018). The dynamics of Zakat donation experience among Muslims: a phenomenological inquiry. Journal of Islamic Accounting and Business Research, 9(1), 45-58.

Lee, R. L., \& Bhattacherjee, A. (2015). A Theoretical Framework For Stragegic Use Of The Web Among Nonprofit Organizations. Proceedings of the Southern Association for Information Systems Conference, Atlanta, GA, USA March 25th-26th, May, 103-1008.

Lee, R. L., \& Joseph, R. C. (2013). An examination of web disclosure and organizational transparency. Computers in Human Behavior, 29(6), 22182224.

Malik, M. (2016). Foundations of Islamic Governance. In Foundations of Islamic Governance.

Mediawati, E. (2016). Internal Control and Quality of Financial Reporting in Zakat Management Organization. 15, 17-19.

Mestika, Z. (2008). Metode Penelitian Kepustakaanes. Yayasan Obor.

Murtala, M., Abioye, O., Har, M., \& Mohamad, S. (2011). Antecedents of Zakat Payers' Trust: The Case of Nigeria. International Journal of Economics, Management and Accounting, 19(3), 133-164.

Nasri, R., Aeni, N., \& Haque, M. G. (2019). Determination of Professionalism and Transparency and its Implications for The Financial Performance of Zakat Institutions. Journal of Islamic Monetary Economics and ..., 5(4), 785-806.

Naz'aina. (2015). The Effect of Internal Control System and Amil Competence on the Financial Reporting Quality at Zakat Management Institution Active Member of Zakat Forum in Special Capital City Region Jakarta and West Java Provinces. Procedia - Social and Behavioral Sciences, 211, 753-760.

Nelson, S. P., Sapingi, R., \& Ahmad, M. (2017). Identifying Disclosure Items for Zakat Institutions. SSRN Electronic Journal, 1-11.

Nikmatuniayah, \& M. Marliyati. (2015). Akuntabilitas Laporan Keuangan Lembaga Amil Zakat di Kota Semarang. Mimbar: Jurnal Sosial Dan Pembangunan, 31(2), 485-494.

Nu Htay, S. N., \& Salman, S. A. (2013). Proposed Best Practices of Financial Informatioan Disclosure for Zakat Institutions: A Case Study of Malaysia. Journal of Chemical Information and Modeling, 53(9), 1689-1699.

Pamuncak, M. B., Possumah, B. T., \& Abdul Hamid3, Z. (2018). IFRS based Zakat 
Reporting: Adoption Rational WesternMethod into Institutional Accountability. Journal of Islamic Economics and Business, 3(1), 17-34.

Puskas BAZNAS. (2019). Indeks Transparansi Organisasi Pengelola Zakat (Opz). In Puskas BAZNAS.

Puspitasari, Y., \& dan H. Habiburrochman. (2013). Penerapan PSAK No. 109 Atas Pengungkapan Wajib Dan Sukarela. Jurnal Akuntansi Multiparadigma, 4(3), 479-494.

Qurratu'ain, I., Cahyono, E. F., Rani, L. N., \& Rusmita, S. A. (2020). The Effect of Social Capital and Human Capital on Performance Effectiveness of National Zakat Institutions in Indonesia, Surabaya, Headquarters Experiences. 117(Gcbme 2018), 243-246.

Rini, R. (2016). Penerapan Internet Financial Reporting untuk Meningkatkan Akuntabilitas Organisasi Pengelola Zakat. Jurnal Akuntansi Multiparadigma, 7(August 2016), 288-306.

Rizka Nurfadhilah, I., \& Sasongko, C. (2019). Web-Based Accountability in an Islamic Non-Profit Organization: A Case Study of Badan Amil Zakat National in Indonesia. 1st Asia Pacific Business and Economics Conference (APBEC 2018), 89(Apbec 2018), 252-259.

Saad, R.A.J., Farouk, A. U., \& Abdul Kadir, D. (2020). Business zakat compliance behavioral intention in a developing country. Journal of Islamic Accounting and Business Research, 11(2), 511-530.

Saad, R A J, Idris, K. M., Shaari, H., Sawandi, N., \& Derashid, C. (2017). Governance of non-profit organizations: A case of zakat institutions in Malaysia. International Journal of Economic Research, 14(16), 253-265.

Saad, Ram Al Jaffri, Aziz, N. M. A., \& Sawandi, N. (2014). Islamic Accountability Framework in the Zakat Funds Management. Procedia - Social and Behavioral Sciences, 164(August), 508-515.

Samargandi, N. (2018). Can disclosure practices and stakeholder management influence zakat payers ' trust? A Malaysian evidence. BEH - Business and Economic Horizons, 14(2002), 882-893.

Samkin, G., \& Schneider, A. (2010). Accountability, narrative reporting and legitimation: The case of a New Zealand public benefit entity. Accounting, Auditing and Accountability Journal, 23(2), 256-289.

Sapingi, R., \& Nelson, S. P. (2016). Current disclosure practices by Zakat Institutions in Malaysia: An exploratory study. 2nd UUM Qualitative Research Conference 2016, May, 408-416.

Sarman, S. R., Zainon, S., Atan, R., Bakar, Z. A., Yoke, S. K., Ahmad, S. A., \& Shaari, N. H. M. (2015). The Web-Based Accountability Practices in Social Enterprises: Validating the Stakeholder Theory. Procedia Economics and Finance, 31(15), 243-250.

Saxton, G. D., \& Guo, C. (2011). Accountability online: Understanding the webbased accountability practices of nonprofit organizations. Nonprofit and Voluntary Sector Quarterly, 40(2), 270-295.

Shamsuddin, N., Mustaffha, N., \& Johari, N. (2017). Internal Audit in Zakat Institutions: Structure and Operational Activities. Proceeding of the 4th International Conference on Management and Muamalah 2017, 
2017(ICoMM), 623-629.

Shamsuddin, N., Zaini, J. A., Mustaffha, N., \& Johari, N. (2018). Internal Audit Effectiveness in Zakat Institutions from the Perspective of the Auditee. Management \& Accounting Review, 17(3), 17-35.

Sulaiman, N., Shukor, Z. A., Arowolo, R. O., Che-ahmad, A., Malik, S. A., Ahmad, A. C., Ridhuan, M., Abdul, C., \& Ahmed, R. M. (2017). A Case Study of Internal Control Practices in Islamic Non-Profit Organizations in Malaysia. Asian Journal of Accounting and Governance, 13-25.

Taha, R., Adam, F., Ali, N. N. M., \& Ariff, A. M. (2017). Religiosity and Transparency in the Management of Zakat Institutions. Journal of Legal, Ethical and Regulatory Issues, 20(1), 1-9.

Tahliani, H. (2018). Contribution of Good Governance Principles to Strengthening Zakat Management in Indonesia: Confirmatory Factor Analysis. International Journal of Zakat, 3(3), 39-54.

Tapanjeh, A. M. (2009). Corporate governance from the Islamic perspective: A comparative analysis with OECD principles. Critical Perspectives On Accounting, 20, 556-567.

Triyuwono, I. (2001). Metafora Zakat Dan Shari'Ah Enterprise Theory Sebagai Konsep Dasar Dalam Membentuk Akuntansi Syari'Ah. Jurnal Akuntansi Dan Auditing Indonesia, 5(2), 131-145.

Verbruggen, S., Christiaens, J., \& Milis, K. (2011). Can resource dependence and coercive isomorphism explain nonprofit organizations' compliance with reporting standards? Nonprofit and Voluntary Sector Quarterly, 40(1), 5-32.

Wulan, M., Khairunnisa, H., \& Bahri, E. S. (2018). Internal Audit Role in Digital Zakat Finance: Case Study at a Zakat Institution in Indonesia. International Conference of Zakat, 179-194.

Zadjuli, S. I., Shofawati, A., \& Muryani. (2020). Bussecon Review of Social Sciences Implementing good corporate governance in zakat institution. Bussecon Review of Social Sciences, 2(1), 27-37.

Zainon, S., Atan, R., \& Wah, Y. B. (2014). An empirical study on the determinants of information disclosure of Malaysian non-profit organizations. Asian Review of Accounting, 22(1), 35-55. 